\title{
Persepsi Siswa Tentang Pengelolaan Pembelajaran Oleh Pamong Belajar Di Sanggar Kegiatan Belajar Kabupaten Padang Pariaman
}

\author{
Wira Marnia ${ }^{1}$ Jasrial $^{2}$ \\ 1,2 Administrasi Pendidikan,Universitas Negeri Padang \\ *Penulis 1, e-mail: wiramarnia90@gmail.com \\ Penulis $1^{2}$, e-mail: jasrial@gmail.com
}

\begin{abstract}
This research is based on the author's observations at the Learning Activity (SKB), Padang Pariaman, that there is an indication that the learning management carried out by the Pamong Belajar is not optimal. The purpose of this study was to describe how well the students' perceptions of learning management by Pamong Belajar in SKB, Padang Pariaman district included: 1) learning planning, 2) learning implementation, 3) learning evaluation. This research is descriptive. The population in this study were students in the Learning Activity Center Kab. Padang Pariaman with a total of 230 students, a sample of 77 people using the Slovin Formula and percentage calculations. The data collection tool was a questionnaire with scale model, with the data being analyzed using the mean formula. These results showed the students' perceptions about the management of learning by Pamong Belajar in the SKB, Kab. Padang Pariaman seen from aspect: 1) Learning planning is in the good category with an average score of 3.92 , with an achievement level of $78.4 \%, 2$ ) The implementation of learning is in a good category with an average score of 4.23 , with the level of achievement $84.6 \%, 3$ ) The learning evaluation is in the good category, with an average score of 4.39 , with an achievement level of $87.8 \%, 4$ ) Overall students' perceptions about the management of learning by Pamong Belajar in the Learning Activity Center, Kab. Padang Pariaman is in the good category, with an average score of 3.97, with an achievement level of $79.4 \%$. Based on the results of the research, it shows that the management of learning carried out by the Pamong Belajar has gone well in the aspects of learning planning, implementation of learning and learning evaluation.
\end{abstract}

\begin{abstract}
Abstrak
Penelitian ini berdasarkan observasi penulis di Sanggar Kegiatan Belajar (SKB) Kab. Padang Pariaman bahwa terdapat indikasi bahwa pengelolaan pembelajaran yang dilakukan oleh pamong belajar belum optimal. Tujuan dari penelitian ini untuk menggambarkan seberapa baik persepsi siswa tentang pengelolaan pembelajaran oleh pamong belajar di SKB Kab. Padang Pariaman. meliputi: 1) perencanaan pembelajaran, 2) pelaksanaan pembelajaran, 3) evaluasi pembelajaran. Penelitian ini bersifat deskriptif. Populasi dalam penelitian ini adalah siswa yang berada di SKB Kab. Padang Pariaman dengan jumlah 230 siswa, diambil sampel sebanyak 77 orang dengan rumus Slovin dan perhitungan persentase. Alat pengumpulan data berupa angket dengan model skala, dengan analisis data menggunakan rumus mean. Hasil penelitian ini menunjukan bahwa persepsi siswa tentang pengelolaan pembelajaran oleh pamong belajar di Sanggar Kegiatan Belajar Kab. Padang Pariaman dilihat dari aspek 1) perencanaan pembelajaran memiliki kategori baik dengan skor hasilnya 3.92 dengan tingkat ketercapaian 78,4\%, 2) pelaksanaan pembelajaran dalam kategori baik dengan skor rata-rata 4.23 dengan tingkat pencapaian $84.6 \%$, 3) evaluasi pembelajaran dengan kategori baik dengan skor rata-rata 4.39 dengan tingkat ketercapaian 87.8\%, 4) secara keseluruhan persepsi siswa tentang Pengelolaan Pembelajaran Oleh Pamong Belajar Di Sanggar Kegiatan Belajar Kab. Padang Pariaman termasuk dalam kategori baik dengan skor temuan 3.97 dengan tingkat ketercapain 79.4\%. Berdasarkan hasil penelitian menunjukan bahwa pengaturan dalam proses pembelajaran yang dilakukan oleh Pamong Belajar sudah berjalan dengan baik dalam aspek perencanaan pembelajaran, pelaksanaan pembelajaran dan evaluasi pembelajaran.
\end{abstract}

Kata Kunci:Pengelolaan; Pembelajaran; Pamong Belajar 
How To Cite: Marnia, Wira dan Jasrial. 2021. Persepsi Siswa Tentang Pengelolaan Pembelajaran Oleh Pamong Belajar Di Sanggar Kegiatan Belajar Kabupaten.Padang Pariaman. Journal of Educational Administration and Leadership, Vol 1 (3): pp. XX-XX, DOI: https://doi.org/10.24036/jeal.v1i3

This is an open access article distributed under the Creative Commons 4.0 Attribution License, which permits unrestricted use, distribution, and reproduction in any medium, provided the original work is properly cited. (O2020 by author.

\section{Pendahuluan}

Pendidikan adalah suatu kebutuhan manusia untuk meningkatkan kualitas hidup demi mencapai kehidupan yang sejahtera dan maju. Pendidikan adalah suatu proses untuk mengembangkan potensi diri dalam bentuk pembelajaran formal, informal dan nonformal untuk mencapai tujuan pendidikan. Dalam meningkatkan pendidikan maka pendidik dan tenaga kependidikan melakukan kegiatan pengelolaan. Pengelolaan adalah suatu proses memberdayakan sumber daya untuk memperoleh harapan yang dicita-citakan. Sedangkan (Aqib, 2013), menjelaskan, proses belajar adalah kegiatan yang terstruktur yang dilakukan oleh guru untuk menciptakan proses belajar mengajar yang efektif dan efisien.. Kegiatan pembelajaran berfokus untuk membangun seluruh potensi yang dipunyai oleh peserta didik agar personal dapat mempunyai keahlian yang diharapkan melalui upaya menumbuhkan serta meningkatkan pengetahuan, perilaku dan kemampuan(Hosnan, 2014). Pengelolaan pembelajaran adalah proses untuk mengelola aktivitas belajar yang berlandaskan pada konsep-konsep dan prinsip-prinsip pendidikan yang bertujuan untuk mencapai keberhasilan belajar berawal dari menentukan strategi, perencanaan serta diakhiri dengan penilaian. Pengelolaan pembelajaran yang baik dapat dilaksanakan oleh pendidik yang profesional dengan memiliki kompetensi yang meliputi: sikap, ilmu pengetahuan, kemampuan baik yang bersifat individu, kelompok maupun bidang pendidikan. Salah satu keahliannya adalah mengelolah pembelajaran. Menurut (Yanti, 2014), menjelaskan bahwa pendidik kerap sekali menjadi sumber inti dalam mentransferkan ilmu dan nilai-nilai kepada peserta didik dalam bentuk proses pembelajaran. Maka dari itu tenaga pendidik harus mampu menguasai ilmu pengetahuan. Tenaga pendidik yang dimaksud disini adalah pamong belajar, pamong belajar adalah guru yang berada di pendidikan nonformal yang diselenggarakan di lembaga daerah seperti Sanggar Kegiatan Belajar (SKB). Pamong belajar sebagai pemangku jabatan fungsional harus mempunyai kemampuan dan kecakapan agar tercapainya keberhasilan dalam melaksanakan tugas dan kewajibannya.

Pengelolaan pembelajaran yang dilakukan oleh pamong belajar hendaklah memberikan manfaat bagi masyarakat untuk meningkatkan mutu dan pelayanan terhadap program sesuai dengan dinamika kebutuhan belajar. Untuk dapat menghasilkan output yang berkualitas maka dilakukannya proses mengatur pembelajaran oleh pendidik dan tenaga kependidikan. Pengelolaan pembelajaran adalah pengelolaan terhadap aktivitas pendidikan, melaksanakan proses pembelajaran, mengevaluasi hasil pembelajaran, mengatur kelas, mengatur tempat duduk, kehadiran siswa, mengatur bahan ajar, mengelola waktu belajar dan mengelola perilaku mengajar. Menurut (Naway, 2016), menunjukan bahwa pengelolaan pembelajaran adalah proses pengajaran yang diatur oleh pendidik melalui tahap perencanaan, pelaksanaan, pengorganisasian dan evaluasi serta kepemimpinan yang bertujuan agar proses belajar mengajar dapat bekerja secara optimal.

Pengelolaan pembelajaran bertujuan, untuk siswa agar meningkatkan kemampuan dalam menggunakan sarana-sarana, menciptakan kondisi yang dapat memenuhi kebutuhan pelajar serta membantu siswa dalam mendapatkan hasil yang dicapai. Dalam mengoptimalkan proses belajar mengajar maka pendidik harus mampu mengelola siswa, alat mengajar dan dapat mengaturnya pada kondisi yang menyenangkan untuk memperoleh tujuan pendidikan dan didukung oleh interaksi antara guru dengan siswa. Menurut (Abu, 2014), bahwa pengelolaan pembelajaran pada dasarnya tercantum ke dalam tujuan pendidikan, yaitu tercapainya keserasian antara perencanaan yang telah dibuat dengan kenyataan yang ada di lapangan serta membantu peserta didik untuk belajar secara efektif sehingga peserta didik dapat memperoleh hasil yang diharapkan. Hal ini dilandaskan pada target, sasaran, dan tujuan akhir pembelajaran yaitu terselenggaranya semua kegiatan, termanfaatnya komponen-komponen pembelajaran dan meningkatnya pengetahuan dan keterampilan. Hasil penemuan yang dilakukan (Tobing, 2019), menjelaskan bahwa pengelolaan pembelajaran yang dilakukan oleh guru belum berjalan dengan optimal, dapat terlihat bahwa siswa kurang respon pada materi pembelajaran, siswa kurang memahami materi pembelajaran. Sedangkan menurut (Marasabessy, 2012), ditemukannya pengelolaan pembelajaran belum berjalan dengan maksimal dilihat bahwa guru belum menguasai kelas, guru belum bisa menggunakan media pembelajaran serta guru belum mampu memahami metode pembelajaran. 
Berdasarkan penelitian (Astowo, 2013), mengemukakan pengelolaan pembelajaran belum sesuai dengan yang diharapkan seperti tidak tepat waktunya guru dalam mempersiapkan bahan ajar, guru kurang mampu dalam mengelolah interaksi proses pembelajaran, guru kurang memahami strategi pengajaran.

Berdasarkan hasil observasi, terdapat fenomena-fenomena yang terlihat sebagai berikut: pembuatan RPP yang belum sempurna, masih kurangnya kemampuan pendidik nonformal dalam menggunakan media pembelajaran di dalam kegiatan mengajar, kurangnya inovasi sebagian pamong belajar untuk kegiatan awal pembelajaran yang baru supaya siswa dapat ikut serta di kelas, nilai dan kemampuan siswa yang semakin rendah dan mengalami penurunan nilai, masih lemahnya kemampuan pamong belajar dalam menciptakan model pembelajaran sehingga proses pembelajaran menonton, masih rendahnya kemampuan pamong belajar dalam menguasai bahan ajar sehingga siswa tidak mampu memahami materi yang disampaikan, terdapatkan deskriminasi nilai yang dilakukan sebagian pamong belajar. Untuk memfokuskan kendala yang akan dibahas supaya masalah yang diteliti tidak menyebar luas mengingat begitu banyaknya ruang lingkup pengelolaan pembelajaran serta terbatasnya pengetahuan atau pengalaman siswa dalam mempersepsikan pengelolaan pembelajaran maka penelitian ini membatasi pada persepsi siswa tentang pengelolaan pembelajaran oleh pamong belajar di Sanggar Kegiatan Belajar (SKB ) Kabupaten Padang Pariaman terdiri dari merancang bahan ajar, pelaksanaan dan penilaian hasil belajar. Kegunaan dalam penelitian ini yaitu untuk mengetahui persepsi siswa tentang perencanaan pembelajaran oleh pamong belajar, untuk mengetahui persepsi siswa tentang pelaksanaan pembelajaran oleh pamong belajar, dan untuk mengetahui persepsi siswa tentang evaluasi pembelajaran oleh pamong belajar di Sanggar Kegiatan Belajar Kab. Padang Pariaman.

Yang menjadi pertanyaannya yaitu: seberapa baik persepsi siswa tentang perencanaan pembelajaran oleh pamong belajar di Sanggar Kegiatan Belajar Kab. Padang Pariaman?, seberapa baik persepsi siswa tentang pelaksanaan pembelajaran oleh pamong belajar di SKB Kab. Padang Pariaman?, seberapa baik persepsi siswa tentang evaluasi pembelajaran oleh pamong belajar di Sanggar Kegiatan Belajar Kab. Padang Pariaman?.

\section{Metode Penelitian}

Jenis Penelitiannya yaitu penelitian deskriptif. yang memperlihatkan, mengungkap dan menafsirkan data sebagaimana adanya. Menurut (Creswell, 2016), risert ini adalah temuan yang paling awal diarahkan untuk menunjukan serta menginterpretasikan objek apa adanya. Dengan demikian penelitian ini mendeskripsikan data yang berhubungan dengan persepsi siswa tentang pengelolaan pembelajaran oleh pamong belajar di Sanggar Kegiatan Belajar Kab. Padang Pariaman. Penelitian ini diselenggarakan di Sanggar Kegiatan Belajar Kab. Padang Pariaman selama 1 bulan dimulai pada tanggal 2 November- 20 Desember 2020.

Populasi adalah semua objek yang akan diteliti. Menurut (Sugiyono, 2008), menjelaskan populasi adalah wilayah tertentu yang ditetapkan untuk dijadikan sebagai objek penelitian. Populasi yang dijelaskan disini yaitu seluruh siswa yang berada di Sanggar Kegiatan Belajar Kab. Padang Pariaman yang diambil pada bulan Desember yang berjumlah 320 siswa. Sampelnya adalah 77peserta didik dengan memperoleh rumus Slovin dan Persentase. Pada penarikan sampel dengan teknik Stratified Random Sampling. Instrumen penelitian ini berupa angket. Angket disusun berdasarkan kajian teori dan menggunakan model skala likert dengan menggunakan lima alternatif jawaban yaitu: Selalu (SL), Sering (S), Kadang-kadang (KD), Jarang (JR) dan Tidak Pernah (TP). Pengujian data menggunakan uji validitas dan uji reliabilitas angket. Data yang dikumpulkan, diolah dan dianalisis sesuai dengan tujuan penelitian. Dimulai dengan memverifikasi data ialah mengoreksi seluruh angket yang diisi oleh siswa, memberikan skor masing-masing alternatif jawaban, mengklasifikasi dan tabulasi data, membuat tingkat pencapain jawaban responden, menghitung perolehan jawaban dengan rumus Mean dan membuat kategori dari hasil temuan.

\section{Hasil dan Pembahasan Hasil Penelitian}

Hasil temuan ini bertujuan untuk mendeskripsikan tentang Pengelolaan Pembelajaran Oleh Pamong Belajar Di Sanggar Kegiatan Belajar Kab. Padang Pariaman.

\section{Perencanaan Pembelajaran}

Perencanaan pembelajaran adalah kegiatan untuk menentukan program, metode-metode dan prosedurprosedur tertentu terkait dengan pengajaran. Perencanaan pembelajaran yaitu proses menyusun kegiatan belajar mengajar yang mencangkup penyusunan silabus dan rencana pelaksanaan pembelajaran (RPP). 
Berdasarkan hasil temuan diatas membuktikan bahwa persepsi siswa tentang perencanaan pembelajaran berdasarkan penyusunan silabus sudah berjalan dengan baikdengan skor perolehan 3.96 pada tingkat pencapain $79,2 \%$, sesuai aturan-aturan yang ada dalam bidang pendidikan. Persepsi siswa tentang perencanaan pembelajaran berdasarkan aspek penyusunan RPP dikategorikan baik dengan skor hasil 3.87 dengan tingkat pencapain $77,4 \%$, Ini menunjukan bahwa perencanaan pembelajaran berdasarkan penyusunan RPP telah berjalan dengan optimal dalam pendidikan nonformal, bahwa perencanaan pembelajaran yang dijalankan oleh pamong belajar telah sesuai, hal ini dijelaskan bahwa Rencana pelaksanaan pembelajaran (RPP) dan silabus adalah pedoman dalam kegiatan siswa untuk mencapai kompetensi dasar dalam belajar. Secara keseluruhan guru harus merancang rencana perangkat pembelajaran secara terstruktur supaya pembelajaran dapat berinteraktif, inspiratif, tidak menonton, bergairah dalam belajar, mendorong semangat peserta didik agar ikut aktif dan memberikan kebebasan siswa dalam berpendapat, serta mandiri supaya anak didik mempunyai kemampuan, minat dan perkembangan fisik serta psikologisnya, dan guru juga harus mempertahankan dan menciptakan perencanaan pembelajaran yang baik sesuai kebutuhan dan karakteristik siswa sehingga dapat menghasilkan output yang berkualitas dan bisa produktif.

Tabel 1.Distribusi Data Persepsi Siswa Tentang Perencanaan Pembelajaran Oleh Pamong Belajar

\begin{tabular}{|lllll|}
\hline No & Sub Indikator & $\begin{array}{l}\text { Rata- } \\
\text { rata }\end{array}$ & $\begin{array}{l}\text { Tingkat } \\
\text { Capaian } \\
(\%)\end{array}$ & Kategori \\
\hline 1 & Penyusunan Silabus & 3.96 & $79,2 \%$ & Baik \\
& $\begin{array}{l}\text { Penyusunan } \\
\text { Rencana } \\
\text { Pelaksanaan } \\
\text { Pembelajaran } \\
\text { (RPP) }\end{array}$ & 3.87 & $77.4 \%$ & Baik \\
& & & \\
Rata - rata & 3.92 & $78.4 \%$ & Baik \\
\hline
\end{tabular}

\section{Pelaksanaan Pembelajaran}

Pelaksanaan pembelajaran merupakan suatu aktivitas yang diarahkan berdasarkan tahap-tahap tertentu agar kegiatan dapat memperoleh hasil yang diinginkan (Sudjana, 2010). Pada pelaksanaan pembelajaran, pendidik melaksanakan langkah-langkah dalam memulai pembelajaran yaitu: kegiatan pendahuluan, inti, dan penutup.

Berdasarkan hasil temuan, menunjukan bahwa persepsi siswa tentang pengelolaan pembelajaran oleh pendidik nonformal di SKB Kab. Padang Pariaman dalam aspek pelaksanaan pembelajaran berdasarkan pada kegiatan pendahuluan dengan skor rata-rata 3.98 dengan tingkat pencapaian 79,6\% dikategorikan baik. Hal ini menunjukan bahwa tanggapan siswa tentang pelaksanaan pembelajaran berdasarkan pada kegiatan pendahuluan, sudah berjalan dengan baik.Pada persepsi siswa tentang pelaksanaan pembelajaran berdasarkan kegiatan inti di kategori baik dengan skor perolehan 4.30 dengan tingkat pencapain $86,0 \%$. Dan pada persepsi siswa tentang pelaksanaan pembelajaran berdasarkan aspek kegiatan penutup berada pada kategori baik dengan skor rata-rata 4.41 dengan tingkat pencapaian $88,2 \%$. Hal ini membuktikan bahwa pelaksanaan pembelajaran pada kegiatan inti dan penutup sudah melakukannya dengan baik, namun guru haruskah mempertahankan dan mengembangkan proses pembelajaran kearah yang lebih baik.

Tabel 2.Distribusi data persepsi siswa tentang pelaksanaan pembelajaran oleh pamong belajar

\begin{tabular}{|lllll|}
\hline No & Sub Indikator & Rata-rata & $\begin{array}{l}\text { Tingkat } \\
\text { Capaian }(\%)\end{array}$ & Kategori \\
\hline 1 & $\begin{array}{l}\text { Kegiatan } \\
\text { Pendahuluan }\end{array}$ & 3.98 & $79,6 \%$ & Baik \\
\hline
\end{tabular}




\section{Evaluasi Pembelajaran}

Evaluasi pembelajaran adalah aktivitas yang dilakukan untuk menetapkan nilai pencapaian belajar seseorang setelah ia menjalankan proses belajar selama satu semester. Penilaian hasil belajar mengajar dapat dinilai dari dua aspek yaitu evaluasi proses pelaksanaan pembelajaran dan hasil belajar.

Berdasarkan hasil ini menunjukan bahwa pengelolaan pembelajaran dari aspek evaluasi pembelajaran telah dilakukan dengan baik, evaluasi berguna untuk memberikan umpan balik kepada guru untuk memperbaiki proses belajar dan terus meningkatkan kemampuan peserta didik. Penelitian menjelaskan bahwa persepsi siswa tentang evaluasi pembelajaran berdasarkan aspek evaluasi proses pelaksanaan pembelajaran dengan skor perolehan 4.41 dengan tingkat pencapain $88.2 \%$ dalam kategori baik. Temuan ini menjelaskan bahwa evaluasi pembelajaran dalam aspek evaluasi proses pelaksanaan pembelajaran telah terlaksana dengan baik dengan mengikuti prosedur perencanaan pembelajaran yang telah dibuat oleh guru. Pada persepsi siswa tentang evaluasi pembelajaran berdasarkan aspek hasil belajar memiliki kategori baik dengan skor rata-rata 4.36 dengan tingkat pencapain $87.2 \%$.Tujuan diadakannya evaluasi pembelajaran supaya siswa mengetahui tingkat kemampuannya selama mengikuti kegiatan pembelajarandan guru memperoleh informasi mengenai potensi siswanya selama kegiatan belajar

Tabel 3. Distribusi data persepsi siswa tentang evaluasi pembelajaran oleh pamong belajar

\begin{tabular}{|lllll|}
\hline No & Sub Indikator & Rata-rata & $\begin{array}{l}\text { Tingkat } \\
\text { Capaian } \\
(\%)\end{array}$ & Kategori \\
\hline 1 & $\begin{array}{l}\text { Evaluasi proses } \\
\text { pelaksanaan } \\
\text { pembelajaran }\end{array}$ & 4.4 .1 & $88.2 \%$ & Baik \\
2 & $\begin{array}{l}\text { Evaluasi hasil } \\
\text { belajar }\end{array}$ & 4.36 & $87.2 \%$ & Baik \\
& Rata-rata & 4.39 & $87.8 \%$ & Baik \\
\hline
\end{tabular}

\section{Pengelolaan Pembelajaran}

Pengelolaan pembelajaran adalah kegiatan untuk mengatur bahan ajar dan komponen-komponen belajar yang dilakukan oleh guru supaya pembelajaran dapat terarah dan bisa memperoleh keinginan pendidikan yaitu menjadikan manusia yang berguna bagi bangsa dan Negara. Kegiatan dalam mengatur pembelajaran diatur melalui tahap perencanaan, pelaksanaan dan penilaian.

Berdasarkan hasil temuan ini menjelaskan bahwa pengaturan dalam proses belajar oleh Pamong Belajar telah terlaksana dengan baik. pendidik, kepala sekolah bekerja sama dalam menciptakan pengelolaan pembelajaran yang baik. Kelancaran proses pembelajaran di kelas tentu akan dapat diwujudkan ketika guru mampu mengelola kelas dan menghasilkan suasana yang kondusif yang pada akhirnya dapat meningkatkan kegiatan pembelajaran.Dari hasil penelitian menunjukan bahwa persepsi siswa tentang pengelolaan pembelajaran oleh pamong belajar di SKB Kab. Padang Pariaman. berada di kategori baik dengan skor ratarata 3.97 dengan tingkat pencapain $79,4 \%$. Dengan pengelolaan pembelajaran, guru mampu menjalankan dan mengontrol aktivitas kelas, misalnya mengatur ruang kelas, kebersihan kelas, perabotan kelas, strategi tempat duduk, kehadiran siswa dan hal sebagainya. Guru bisa merancang strategi belajar apabila terjadinya hambatan dan tantangan untuk memperoleh hasil yang diharapkan. Tujuan utama dari pengelolaan pembelajaran adalah untuk menghemat waktu dan tenaga dalam menyediakan kondisi yang efektif dalam menjalankan aktivitas secara ekonomis dan efisien. Hal ini sejalan dengan pendapat (Djamarah, 2002), menjelaskan bahwa tujuan 
dalam pengelolaan pembelajaran dilakukan agar setiap siswa dapat belajar dan bekerja dengan tertib sehingga tercapai tujuan pembelajaran secara efektif dan efisien. Secara khusus pengelolaan pembelajaran dimaksudkan untuk mengembangkan kemampuan siswa dalam menggunakan alternatif belajar, memperoleh kondisi yang memungkinkan siswa belajar, serta membantu siswa memperoleh hasil yang diharapkan. Kondisi belajar akan optimal jika pengajar atau guru mampu mengelola siswa dan alat-alat pembelajaran serta mengendalikannya dalam suasana yang kondusif untuk mencapai tujuan pengajaran. Keberhasilan pengelolaan juga didukung oleh hubungan interpersonal yang baik antara guru dengan siswa.

Tabel 4. Distribusi data persepis sisiwa tentang pengelolaan pembelajaran oleh pamong belajar

\begin{tabular}{|lllcc|}
\hline No & Sub Indikator & Rata-rata & Tingkat Capaian (\%) & Kategori \\
\hline 1 & Perencanaan Pembelajaran & 3.92 & $78.4 \%$ & Baik \\
2 & Pelaksanaan Pembelajaran & 4.23 & $84.6 \%$ & Baik \\
3 & Evaluasi Pembelajaran & 4.39 & $87.8 \%$ & Baik \\
& & & & Baik \\
\hline
\end{tabular}

\section{Pembahasan}

Persepsi siswa tentang perencanaan pembelajaran oleh pamong belajar di SKB Kab. Padang Pariaman

Perencanaan yaitu kegiatan pengelolaan dengan berlandaskan apa harus dikerjakan serta apa yang harus dipersiapkan. Sedangkan pembelajaran yaitu proses kegiatan belajar mengajar yang dilaksanakan oleh sumber belajar. Menurut(Azwardi, 2015), menjelaskan perencanaan pembelajaran adalah langkah awal dalam penyusunan komponen-komponen pembelajaran.Menurut (Agus, 2015), menjelaskan bahwa pada rencana pembelajaran terdapat hal- hal yang dipersiapkan oleh guru yaitu perangkat pembelajaran yang mencangkupnama pembelajaran, mata pelajaran, materi pelajaran, standar kompetensi, kompetensi dasar, indikator pencapaian, alokasi waktu, kegiatan belajar, sumber daya dan penilaian pada hasil belajar. Menurut (Agus, 2015), perencanaan pembelajaran adalah sesuatu yang harus dikerjakan oleh pendidik terlebih dahulu sebelum melakukan proses belajar. Kalau perencanaan pembelajaran tidak dibuat maka tidak adanya arah dan pedoman dalam mengajar. Pada perencanaan pembelajaran seluruh guru harus menyediakan RPP dan silabus.

Upaya pendidik dalam menciptakan perencanaan pembelajaran dengan baik yaitu memenuhi kebutuhan dan memahami karakteristik peserta didik. (Dimyati \& Mudjiono, 2009), menjelaskan upaya guru dalam menyusun perencanaan pembelajaran sebagai berikut: guru harus memahami apa itu tujuan pendidikan, menguasai bahan ajar adalah hal yang harus dilakukan, teori-teori pendidikan harus dipahami, prinsip-prinsip mengajar, metode-metode pengajaran pendidik harus dikuasai, dan memahami teori-teori pengajaran.

Persepsi siswa tentang pelaksanaan pembelajaran oleh pamong belajar di SKB Kab. Padang Pariaman

Pelaksanaan pembelajaran merupakansebuah hubungan yang dijalankan antara guru dengan murid dalam memperoleh proses mengajar yang baik. Menurut (Suryosubroto, 2002), menjelaskan bahwa pelaksanaan pembelajaran merupakan proses terciptanya kerjasama antara pendidik dengan murid dalam rangka memberikan materi pelajaran demi mencapai tujuan pendidikan. Menurut Permendiknas No. 41 Tahun 2007, menjelaskan bahwa kegiatan pembelajaran yaitu aktivitas yang terjadi di dalam lingkungan pendidikan berupa hubungan kerja sama yang terjalin antara sumber belajar dengan pelajar. Pada pembelajaran kewajiban dan tanggung jawab seorang guru adalah mengatur lingkungan untuk mendorong terjadinya perubahan sikap dari siswa. Menurut (Kusrini, 2009), menjelaskan bahwa guru dalam menyusun silabus hendaklah sesuai dengan kurikulum yang ada di suatu sekolah dan guru harus berinteraksi dengan siswa pada proses belajarmelalui penerapan berbagai cara-cara, metode dan teknik pembelajaran serta penggunaan perangkat media. Adapun aspek yang dilakukan dalam pembelajaran yaitu kegiatan pendahuluan, inti, dan penutup.

Hal-hal yang dilaksanakan pendidik dalam proses belajar yang baik kepada siswa agar materi pelajaran bisa dikuasai oleh pelajar maka secara umum pendidikan bisa dijalankan dengan optimal, dengan guru 
memberikan bertanya jawab dan memberikan tekanan dapat berupa lisan, tulisan, maupun pemberian hadiah terhadap keberhasilan siswa, memfasilitaskan siswa dalam menjalankan aktivitas yang menumbuhkan kebanggaan dan rasa percaya diri siswa dan menciptakan suasana pembelajaran yang menyenangkan bagi siswa sehingga materi ajar bisa dikuasai. Menurut (Kusrini, 2009), menjelaskan bahwa upaya guru dalam menciptakan pelaksanaan pembelajaran yang baik yaitu: memberikan peserta didik kebebasan dalam memberikan pendapat di depan kelas, menyambut peserta didik dengan senyuman, tidak membeda-bedakan peserta didik baik dari agama, adat, ekonomi dan sosial, membangun hubungan harmonis antara pendidik dengan siswa, membangun semangat dan kerja sama di dalam kelas, menciptakan suasana yang menyenangkan, dan ikut memperhatikan kebutuhan setiap peserta didik.

\section{Persepsi siswa tentang evaluasi pembelajaran oleh pamong belajar di SKB Kab. Padang Pariaman}

Evaluasi pembelajaran merupakan proses untuk memperlihatkan kemampuan siswa dan menimbangnya dalam bentuk nilai dan arti (Arifin, 2017), Penilaian proses pembelajaran merupakan aktivitas yang terstruktur untuk menentukan dan melihat potensi siswa yang dicapainya selama mengikuti proses belajar melalui penilaian. Evaluasi pembelajaran adalah suatu kegiatan yang dinilai untuk melihat seberapa jauhnya tingkat pencapaian kemampuan, pemahaman terhadap materi serta menilai peningkatan belajar, dan melakukan perbaikan secara berkelanjutan. Menurut Undang-Undang Republik Indonesia No 20 Tahun 2003, menjelaskan bahwa penilaian dilakukan dalam rangka mengendalikan mutu pendidikan secara nasional bersifat akuntabilitas dalampenyelenggaraan pendidikan kepada pihak-pihak yang berkepentingan diantaranya terhadap siswa, lembaga dan program pendidikan. Aspek dalam penilaian kegiatan belajar terdiri dari dua jenis yaitu evaluasi proses pelaksanaan pembelajaran dan evaluasi hasil belajar.

Menurut Peraturan Menteri Pendidikan Dan Kebudayaan Republik Indonesia No. 23 Tahun 2016 tentang standar penilaian pendidikan menjelaskan bahwa upaya guru dalam meningkatkan kualitas penilaian pembelajaran dapat dilakukan dengan cara sebagai berikut: penilaian hasil belajar oleh pendidik dilakukan dalam bentuk ulangan, pengamatan, penugasan dan bentuk lainnya, dan penilaian hasil belajar oleh pendidik dilakukan untuk mengukur dan menggambarkan pencapaian kompetensi peserta didik, memperbaiki proses pembelajaran, dan menyusun laporan kemajuan hasil belajar harian tengah semester, akhir semester, akhir tahun dan kenaikan kelas.

Persepsi siswa tentang pengelolaan pembelajaran oleh pamong belajar di SKB Kab. Padang Pariaman

Pengelolaan pembelajaran adalah kegiatan yang dilakukan oleh pendidik secara terstruktur yang diawali dengan menyusun bahan ajar sampai tahap penilaian. Menurut (Djamarah, 2002), menjelaskan bahwa guru dalam menjalankan kegiatan belajar di sekolah, harus melihat situasi dalam potensi belajar siswa, materi pelajaran. Menyusun strategi untuk mengantisipasi apabila timbul hambatan dan rintangan agar proses belajar mengajar tetap berjalan dan tujuan pembelajaran yang telah ditetapkan dapat berhasil. Untuk menciptakan suasana kelas yang tertib maka guru harus memberikan peraturan yang harus dipatuhi oleh siswa selama proses belajar mengajar berlangsung secara optimal.

Jadi kesimpulan dari hasil temuan ini, secara luas, Persepsi Siswa Tentang Pengelolaan Pembelajaran Oleh Pamong Belajar Di Sanggar Kegiatan Belajar Kab. Padang Pariaman dari indikator perencanaan pembelajaran, pelaksanaan pembelajaran dan evaluasi pembelajaran telah berjalan dengan baik, pada skor rata-ratanya 3.97. Artinya kegiatan pengelolaan pembelajaran tentang perencanaan pembelajaran, pelaksanaan pembelajaran dan evaluasi pembelajaran dikelola dengan baik sehingga membantu siswa dan guru dalam menjalankan kegiatan belajar.

\section{Simpulan}

Berdasarkan hasil penelitian mengenai " Persepsi Siswa Tentang Pengelolaan Pembelajaran Oleh Pamong Belajar Di Sanggar Kegiatan Belajar Kab. Padang Pariaman” dapat ditarik kesimpulan sebagai berikut: Berdasarkan hasil penelitian dan pembahasan yang telah dapat ditarik kesimpulan sebagai berikut: Persepsi siswa tentang perencanaan pembelajaran oleh pamong belajar di SKB Kab. Padang Pariaman berada pada kategori baik dengan skor rata-rata 3.92 dengan tingkat pencapain 78.4\%, Persepsi siswa tentang pelaksanaan pembelajaran oleh pamong belajar di SKB Kab.Padang Pariaman berada pada kategori baik dengan skor ratarata 4.23 dengan tingkat pencapain $84,6 \%$, Persepsi siswa tentang evaluasi pembelajaran oleh pamong belajar di SKB Kab. Padang Pariaman berada pada kategori baik dengan skor rata-rata 4.39 dengan tingkat pencapain 87.8\%, Persepsi siswa tentang pengelolaan pembelajaran oleh pamong belajar di SKB Kab. Padang Pariaman berada pada kategori baik dengan skor rata-rata 3.58 dengan tingkat pencapain $79,4 \%$. 
Kesimpulan diatas dapat kemukakan beberapa saran sebagai berikut: diharapkan pamong belajar dan pihak - pihak yang berada di SKB dapat meningkatkan pengelolaan pembelajaran dengan baik dalam hal, perencanaan pembelajaran, pelaksanaan pembelajaran, dan evaluasi pembelajaran lebih ditingkatkan lagi kearah yang maksima, sehingga dapat meningkatkan kualitas dan potensi siswa, meskipun hasil penelitian ini menunjukan bahwa pengelolaan pembelajaran telah terlaksana dengan baik, pada masa yang akan datang bisa saja terjadinya penurunan menjadi kurang baik, oleh karena itu perlu upaya pihak terkait seperti kepala SKB, Pamong Belajar, dan maupun tenaga administrasi sebagai pengelola, harus bisa mempertahankan dan meningkatkan pengelolaan pembelajaran supaya menjadi pembelajaran yang mampu menghasilkan lulusan yang baik dan kepada penelitian lanjutan diharapkan untuk meneliti lebih lanjut tentang pengelolaan pembelajaran dengan mengambil aspek yang berbeda dan objek yang berbeda pula.

\section{Daftar Rujukan}

Abu, S. N. (2014). Pembinaan Guru Oleh Kepala Sekolah Dalam Pengelolaan Pembelajaran Di Sekolah Dasar. Bahana Manajemen Pendidikan, 705-831.

Agus, R. A. (2015). Strategi Pengelolaan Kelas Dalam Proses Pembelajaran. Jurnal Pendidikan Pedagogik, 125.187

Aqib, Z. (2013). Model- Model Media, Dan Strategi Pembelajaran Kontekstual (Inovatif). Bandung: Yrama Widya.

Arifin, Z. (2017). Evaluasi Pembelajaran; Teknik Dan Prosedur. Evaluasi Pembelajaran: Prinsip-Teknik Prosedur, 160-170

Astowo, P. (2013). Kinerja Guru Dalam Pengelolaan Pembelajaran Di SMK Pemda Padang Panjang . Bahana Manajemen Pendidikan, 173-461.

Azwardi. (2015). Manajemen Pembelajaran Paud. Bandung: Manajer Pendidikan.

Creswell, J. W. (2016). Pendekatan Metode Kualitatif, Kuantitatif Dan Campuran. Edisi Keempat (Cetakan Kesatu)., 50-56.

Dimyati, \& Mudjiono. (2009). Belajar Dan Pembelajaran. Pengaruh Aktivitas Dan Motivasi Belajar Dengan Pembelajaran Portofolio Terhadap Hasil Belajar Geografi, 176-188

Djamarah, S. B. (2002). Strategi Belajar Mengajar. Pengelolaan Pembelajaran Dan Pengembangan Bahan Ajar 150-170

Hosnan, M. (2014). Pendekatan Saintifik Dan Kontekstual Dalam Pembelajaran Abad 2. Peningkatan Kreativitas Dan Hasil Belajar Melalui Model Pembelajaran Discovery, 369-374.

Kusrini, S. (2009). Keterampilan Dasar Mengajar Berorientasi Pada Kurikulum Berbasis Kompetensi . Pengelolaan Pembelajaran Geografi Berbasis Laboratorium Di SMA Negeri 7 Purworejo Tahun 2014 , 156-159

Marasabessy, A. (2012). Pengelolaan Pembelajaran Yang Dilakukan Oleh Guru Yang Sudah Tersetifikasi Dan Yang Belum Terserifikasi Pada Pembelajaran IPA Di Kelas V Sekolah Dasar. Pengelolaan Pembelajaran Di SD Negeri 09 Hilia Lamo Kamang Hiilia Kecamatan Kamang Magek Kabupaten Agam , 50-56.

Naway, F. A. (2016). Strategi Pengelolaan Pembelajaran. Gorontalo: Ideas Publishing.

Peraturan Menteri Pendidikan Dan Kebudayaan Republik Indonesia No. 23 Tahun 2016 Tentang Standar Penilaian Pendidikan

Permendiknas No. 41 Tahun 2007 Tentang Standar Proses 
Wira Marnia ${ }^{1}$ Jasrial $^{2}$ Persepsi Siswa Tentang Pengelolaan Pembelajaran Oleh Pamong Belajar Di Sanggar Kegiatan Belajar Kabupaten. Padang Pariaman

Sudjana, N. (2010). Proses Dan Hasil Belajar. Meningkatkan Hasil Belajar Siswa Dengan Menggunakan Metode Bimbingan Mata Pelajaran IPA Di Kelas III SD Inpres I Bainaa , 190-201

Sugiyono. (2008). Metode Penelitian Pendidikan (Pendekatan Kuantitatif, Kualitatif Dan $R \& D$ ). Bandung: Alfabeta.

Suryosubroto. (2002). Proses Belajar Mengajar Di Sekolah . Pengelolaan Pembelajaran Dalam Meningkatkan Minat Belajar Peserta Parogram Desain Grafis Di Lembaga Kusus Dan Pelatihan Magistra Utama Kota Kediri , 120-130

Tobing, V. M. (2019). Pengaruh Evaluasi Proses Pembelajaran Terhadap Hasil Belajar PAI Di SMA Negeri I Pekalongan Lampung Timur 2018/2019. Lampung: Institusi Agama Islam Negeri Ian Metro.

Undang Republik Indonesia No 20 Tahun 2003 Tentang Sistem Pendidikan Nasional

Yanti, O. (2014). Usaha Kepala Sekolah Dalam Meningkatkan Kreativitas Guru Dalam Pembelajaran Di Sekolah Dasar . Analisis Kreativitas Guru Dalam Proses Belajar Mengajar Pada Pelajaran Ekonomi Kelas XI SMA, 2.10-301 